\title{
The Myth of White Skin: A Postcolonial Review of Cosmetics Ads in Indonesia
}

\author{
Roro Retno Wulan ${ }^{1, *}$ \\ ${ }^{1}$ Telkom University, Jl. Telekomunikasi, Terusan Buah Batu, Bandung Indonesia
}

\begin{abstract}
Cosmetics industry created the beauty myth for women through advertising. A cosmetic ad in Indonesia has spread a new concept of white skin: East Asia beauty myth. The white concept of Asia white skin basically derived from colonial legacy. The purpose of the research was analyzing the beauty myth in Indonesia ads using postcolonial perspective. The principal result brought the discourse analysis and postcolonial perspective a new insight in communication research. Particularly on media and cultural studies. Major conclusions showed that the beauty myth since the Dutch colonial period never been change. The main concept is always in colonialism's idea: "white is better". The West is better than the East.
\end{abstract}

\section{Introduction}

The world's changes have brought women to the positions that are difficult and confusing. The beauty industry had created the myth of global beauty. Women have constructed Western ideal of beauty: a tall-white-skinny-blond hair. Beauty myth maintained and promoted on a large scale by the mass media through advertisements of cosmetics, apparel, and health. The beauty myth enjoyed broad audience through the image of actresses in films, video clips, commercials and billboards hit every household Indonesia. At its core, capitalistic world today have colonized women. In the book "The Beauty Myth: How Images of Beauty Are Used Against Women", Wolf [1] shows that during this time black women, brown women, and white women in America dealing with the myth of beauty to be the perfect person for example: have a tall body, slim, white skin, and blond hair. Their facial skin should not have the slightest flaw and they should be as small waist size. This colonial beauty myth attached to women in colony territory until today. In fact this nature of beauty is subjectivity highly. Each culture has its own construction of what is called a beautiful woman. For example, Karen Tribe in Thailand who sees a beautiful woman whose neck long, another case with the Dayaks in Indonesia which saw a beautiful woman with long-eared. The white women herself is idealizing tanning as beauty while Indonesian women wanted to have white skin.

This is the beauty myth constructed by the colonial settlers from the colonial period. McClintock [2] in her book "Imperial Leather: Race, Gender and Sexuality" describe the relationship between conception clean or white skin color with colonialism. The colonists regarded the natives as the wild and nasty because of their skin color were black (in Africa) and brown (in Asia). The facts of skin color differences become the cornerstone to the imperialists to create social stratification in the colonial and indigenous people were in the lowest layer. Especially women as the subaltern. Her position was never improved. In such conditions it is understood that capitalism has collaborated with patriarchy to construct the women so that never satisfied with her.

On the one hand, patriarchy constantly reproduces itself to perpetuate their power over women as subordinate. On the other side capitalism had lived from women income. The increase number of female workers has been multiplying consumption. At the end, patriarchy in many ways is still trying to subjugate women. Being marginalized is actually

\footnotetext{
*Corresponding author: rorowoelan28@gmail.com
} 
women's problem across Asia and the world, therefore, the study sought to analyze the beauty myth in Indonesia in connection with the proliferation of ads about whiter and brighter skin for women in Indonesia.

\section{Literature Review}

Postcolonial studies are born from the difference between the colonizers and the colonized. This raises the binary opposition of third world women who are fighting against two hegemonies, patriarchy and capitalism as a form of modern imperialism as the colonial heritage. As a study of theory, postcolonial cultural studies departing from cultural studies. It shows how the methodological concepts of postcolonial been explored through the depiction of sexual identity, distinctive character, historically aspect, and flexible. Haris (1983) in Aschroft, Griffiths \& Tiffin [3] explains "Postcolonial texts may deal with divisions of race and culture which are apparently obdurately determined, each text contains the seeds of 'community' which, as they germinate and grow in the mind of the reader, crack asunder the apparently inescapable dialectic of history". Madison [4] argues "Post colonialism refers to the multiple forms and locations of discourse, performance, politics, value, and the "everyday" - both past and present- that emanate from the history of colonialism". Construction of identity does not impartially and not necessary to be feared as long as women have knowledge and know themselves. Thus, self-confidence on the uniqueness of their selves will grow by itself. The terrible thing is a myth. Myths will only live if maintained and the audience agreed with it. This myth if not soon be forgotten, will turn all women into puppet with sameness and uniform identity. On the other hand the birth of postcolonial theory has been open our minds to the concept of white skin became an obsession mostly on Asian women, rooted in the colonial period. The concept of Asian women beauty is certainly not to be compared with Western concept of beauty. Especially the issue of skin color and cleanliness.

\section{Method}

This research used discourse analysis to uncover representation of white skin concept. This research saw white concept as colonial period legacy. The white skin myth viewed as representation of colonial communication process. Lasswell [5] in Titscher et.al [6] stated in content analysis we look upon statements and signs as raw materials to be summarized in order to bring out either (1) the impact of content upon audience, or (2) the influence of control upon content.

If in some sense before the word "discourse" has limit to the definition unit of language, statements, thoughts or grounding determination and understanding of the facts, in the concept of Foucault, discourse implies the existence of power and the power behind these statements. This understanding believes that the power relations in society influencing and shaping the ways we communicate and how the knowledge was created. This research analyzed body lotion advertising in the last five years. They have several products with the specification of white skin branding. These strategies were advertising capabilities in constructing reality and affect the perception of audience. It has brought various changes of social and cultural values. The beauty standard of women is part of the ideal values that have been successfully transformed by advertisements and has become a uniform system as a whole. However, we never aware about intervention of colonial ideology.

\section{Findings and Analysis}

Women in Indonesia are now experiencing the identity distortion in relation to economic autonomy, political, and cultural. The identity distortion as a female identity is defined to be a complement to support the men as part of the patriarchal which can take the form of individual men, government, and country. Patriarchy class is defined as the "father", officials and state apparatus that acts as a protective father.

The loss of women's right to choice their future, like occupation and education, is also an issue to concern. Women were led into the means of production in service industry, manufacturing, or tourism, all of which make sex and female sexuality as a commodity to encourage people to buy service and goods. The problems of women in feudal times as if comes back now with a companion featuring women as a symbol of a husband who acts as a "Prameswari", as complementary under her husband's powers. Women trying to look attractive to be declared as the best for her man. The emergence of the concept of "white" is a legacy of the colonial era, to be a part of the construction of femininity and female sexuality today.

The theme of "white" appeared in several beauty ads lately. Discourse becomes white be dominating. White is not only appearing on soap ads, body lotion, face cleanser cream, face moisturizer, and body powder but also for the product for certain body parts that very intimate. The obsession against white skin and everything is marked up as white in my opinion is not just an obsession with beauty, but more than that ... the obsession with white can be categorized as a colonial nostalgia or even colonial trauma [7]. When colonialism affecting Asia, the imperialists are carrying the culture of "clean". Clean analogous to a clean of uncivilized or civilizing people who are still natural. The Europeans looked black, red, and brown as a dirty form. Dirty is not just the body that naturally colored but further defined 
uncultured. Cleanliness is not merely literally refers to a state free of impurities, since both clean and dirty has social significance, racial and colonial [7]. Desirable white also has the quality to be hyper-real, not just white, but white is soft, smooth, healthy, and radiant. And more than that, being white is to become a global subject. Being beautiful, as recognized by the global community [7].

Now there is a shifting paradigm in the concept of white. Beside western whiteness, there is another whiteness to sell to Indonesia women, Asian white, such as Japan (Shinsui) and China (Tse Fuk). Even Nivea's product sells the whitening product in Indonesia. White concept of East Asia is also preferred since the presence of popular culture from all three countries: Japan, Korea and China. The emerge of K-Pop, Harajuku style and beauty of Chinese women in Hong Kong movies and soap operas has influencing worldwide and colonizing Asian women ideology to becoming white. Indonesian women which born in brown skin seduced to be white, and these body lotions can help them to becoming white. The hyper real condition to change their skin color by using lotion. The advertising had promoted the Asia's Whiteness to make the ideology of white more logical for Indonesian women. In this research, we focused to analyze Citra Body Lotion Product as the one which using Indonesian name. Citra Body Lotion also launched "Rumah Cantik Citra" to help the customer improving their beauty with Citra's products. Citra has gain several recognition as a product with loyalty from its consumer since 2006. Citra claimed their product as the beauty product that knows about Indonesian beauty. Citra promoted how beautiful skin can improve women beauty. Below is how the product changes their ideology for marketing strategic:

Table 1. Citra Body Lotion's Evolution [8].

\begin{tabular}{|c|c|c|c|c|}
\hline No. & 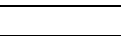 & The A & & Description \\
\hline 1 & 5 wistin & shemi & & $\begin{array}{l}\text { In } 1984 \text { Citra had launched the beauty of Javanese } \\
\text { woman (kuning langsat). It is not selling the whiteness } \\
\text { for the first time. They used natural material from } \\
\text { Indonesia. }\end{array}$ \\
\hline 2 & Citra & citra & & $\begin{array}{l}\text { In } 2006 \text { they launched three new variants and started to } \\
\text { sell the whiteness: Citra Bengkoang White Lotion, } \\
\text { Citra Teh Hijau Beauty Lotion and Citra Mangir } \\
\text { Beauty Lotion }\end{array}$ \\
\hline 3 & 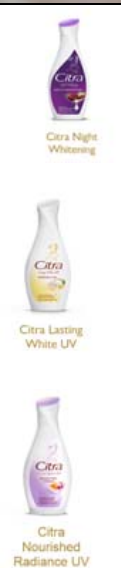 & 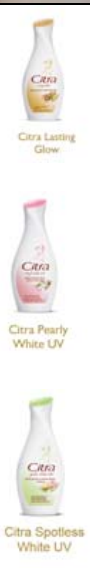 & 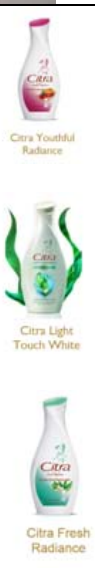 & $\begin{array}{l}\text { Since } 2013 \text { Citra has improved their product to be more } \\
\text { Asian and using Asia whiteness like Japanese Wakame, } \\
\text { Korean Pearl, and Indonesian bengkoang. There are } \\
\text { others variant and using Asian beauty whiteness myths. } \\
\text { Like Korean royal jelly and pearls, Japanese rice, } \\
\text { Japanese green tea, Himalayan Gojiberry, India grapes } \\
\text { oil and almonds. } \\
\text { From ten variants, } 6 \text { of those using the words "white" } \\
\text { to attract consumer buying. } \\
\text { The myth of whiteness assumed as cleanness and } \\
\text { smoothness came from western. McClintock on her } \\
\text { book "Imperial Leather"showed us how the Western } \\
\text { influenced the East about cleanness and whiteness. }\end{array}$ \\
\hline
\end{tabular}

As we seen from the table above, Citra used white representation to sell their products. From the ads we can see how whiteness becomes something good and idolized. White skin color is more than a fantasy; it is a concept to describe beauty to Indonesian women. The current reality is determined by the market. Formerly women flocked make ringlets 
like Marilyn Monroe, but now more and more women who wish to have straight hair as a symbol of beauty from East Asia. Beauty products ads at this time seemed to discredit women to sacrifice the potential of hers and exalt physical perfection.

\section{Conclusion}

The development of communication theories cannot be separated from the development of the civilization. Advances in technology and culture affect the progress of Communication Science. Communication theory is a symbiotic creation that is made to explain the phenomenon that happens and it becomes a pattern that we can observe. The main aim of the theory is to explain, predict, and control the phenomena that occurred or will occur. So, this research tries to give the new insight of Communication. As the function of the theory is organizing experience, develops knowledge, stimulating and directing further research, gave way to the researcher to anticipate events that may not be able to observe [9].The phenomenon of white skin myth on women is based on the colonial ideology should be realized by women in Asia. The struggle against western hegemony will stimulate an increase in political and economic alignments, and directing research on improving the condition of women in post-colonial societies that bear the double burden that is subordinated by colonialism and domination of indigenous men. However, the development of literacy in Gramscian ethics of feminism is part of counter-hegemony to the ideas of masculinity which dominate the world of material and symbolic communities worldwide. The concept of white skin as a beauty construction of an idealization that is not eternal. It is changing with the times and interests.

\section{References}

1. N. Wolf, The Beauty Myth: How Images of Beauty Are Used Against Women. London: Harper Collins. (2002)

2. A. McClintock, Imperial Leather: Race, Gender, \& Sexuality in colonial contest. London: Routledge. (1995)

3. B. Ashcroft, G. Garreth T. Helen, The Empire Writes Back, Theory and Practice in Post-Colonial Literature 2nd Edition. Routledge. London, (2002)

4. S. Madison, Critical Ethnography Method, Ethics, and Performance 2nd Edition. Sage Publication. USA, (2012)

5. H. Lasswell, Describing the Contents of Communication. NJ: Princeton University Press, (1946)

6. Titscher, S., Meyer, M., Wodak, R., \& Vetter, E. (2000). Methods of Text and Discourse Analysis. London: Sage Publications.

7. A. Prabasmoro, Becoming White: Representasi Ras, Kelas, Femininitas dan Globalitas Dalam Iklan Sabun. Bandung: Matahari, (2003)

8. Rumah cantik citra http://www.rumahcantikcitra.co.id

9. D. Infante, A. Rancer, D. Womack, Building Communication Theory 2nd Edition. Illinois: Waveland Press. Inc (1993) 